\title{
A new species of Nemoura (Plecoptera, Nemouridae) from the Abruzzo region (Central Italian Apennines)
}

\author{
G. VINÇON ${ }^{1,3} \&$ A. RUFFONI ${ }^{2}$ \\ ${ }^{1}$ Gilles Vinçon, Bd. Joseph Vallier 55,F-38100 Grenoble, France.Email: gvincon@gmail.com. \\ https://orcid.org/0000-0003-4702-5136 ${ }^{3}$ Corresponding author. \\ ${ }^{2}$ Alexandre Ruffoni, 14 rue Moilleret, F-89200 Lucy-Le-Bois, France.Email: alexandre.ruffoni@gmail.com. \\ https://orcid.org/0000-0002-5754-7838
}

\begin{abstract}
Riassunto. Una nuova specie di Nemoura Latreille, 1796, N. aprutiana n. sp., dell'Italia centrale, (Appennino Abruzzese), è descritta e illustrata, mettendo in risalto i caratteri morfologici che la differenziano dalle tre specie sorelle italiane $N$. hesperiae Consiglio, 1960, N. lucana Nicolai \& Fochetti, 1991 e N. palliventris Aubert, 1953. Sono inoltre fornite notizie sulla distribuzione e sulle preferenze ecologiche di questa nuova specie e una carta di distribuzione nella Regione Italica delle quattro specie sorelle.
\end{abstract}

Abstract. A new species of Nemoura Latreille, 1796, N. aprutiana sp. n., from the Italian Abruzzo region in the central part of the Apennines, is described and illustrated, and compared to its three Italian sister species $N$. hesperiae Consiglio, 1960, $N$. lucana Nicolai \& Fochetti, 1991 and N. palliventris Aubert, 1953. Information on the distribution and ecological preferences of this new species is also provided, as well as a distribution map of the four Italian sister species.

Keywords. stoneflies, Italy, Nemoura aprutiana sp. n., N. hesperiae, N. lucana, N. palliventris.

\section{INTRODUCTION}

I ntensive collecting of Plecoptera conducted in the Italian Alps and Apennines in 2020 and 2021 by the first author (Vinçon, Reding \& Ravizza 2021, Vinçon, Ravizza \& Reding 2022) has resulted in the discovery of a new Nemoura species, Nemoura aprutiana sp. nov. described in this contribution and compared to three other morphologically close Italian species: $N$. hesperiae Consiglio, 1960, N. lucana Nicolai \& Fochetti, 1991 and N. palliventris Aubert, 1953. This group of four species is also related to three Balkanic species: N. flaviscapa Aubert, 1956a, N. vinconi Murányi, 2007 and N. zwicki Sivec, 1980, and to one Alpine species N. obtusa Ris, 1902, all having similar epiproct characterized by its shield-shaped apical sclerite (Figs. 3-5). Nevertheless, in this group $N$. obtusa clearly differs by the rather unique shape of its cerci. Several misidentifications concerning these species occur in some collections: $N$. hesperiae was wrongly assigned to N. erratica (Consiglio 1958); N. palliventris wrongly assigned to $N$. hesperiae (Ravizza
1974, 1976, Ravizza \& Ravizza Dematteis 1977) (Ravizza in lit.), indeed the identification of $N$. hesperiae or $N$. palliventris needs careful study of the epiproct in dorsal view and even also with the epiproct slightly raised since the shape of the apical sclerite looks very different according to the viewing angle and may induce misidentifications; therefore we give comparative descriptions of the 4 different species, with 3 different viewing angles (Figs. 3, 4, 5).

\section{MATERIAL AND METHODS}

Adults were collected with using a "Japanese umbrella" (beating screen).

Terminology used follows Baumann (1975). Abbreviations used: br. = brook, N. = North, R. = River, spr. $=$ spring, tor. $=$ torrent, $($ RED $)=$ Reding collection, (RUF) = Ruffoni collection, $(\mathrm{VIN})=$ Vinçon collection .

In the figures $(2-5,7-9)$, comparative description of $N$. hesperiae is based on specimens col- 
lected in the Abruzzi (Maiella Massif, $1720 \mathrm{~m}$ ) nearly $40 \mathrm{kms}$ from the type locality of $N$. hesperiae; the comparison of $N$. lucana is based on a male collected in Southern Italy (Basilicata: Pollino, $1600-1650 \mathrm{~m}$ ), nearly $100 \mathrm{kms}$ from the type locality of $N$. lucana and the one of $N$. palliventris is based on specimens collected in the Sila Massif $(1580-1650 \mathrm{~m})$, close to the type locality (Sila, Mucone).

Illustrations of the specimens were produced by the second author with the help of a stacking device connected to a Canon 550d with a $100 \mathrm{~mm}$ Canon macro lens or $200 \mathrm{~mm}$ Pentacon lens associated with an infinite Nikon CFI 10x lens; the whole is piloted by a Cognisys Stackshot. The images were assembled with Zerene Stacker (V1.04). The map and habitat photographs were provided by the first author.

All specimens are preserved in $70 \%$ ethanol. Holotype and a part of the paratypes are deposited in the Museum of Zoology, Lausanne, Switzerland (MZL). Several paratypes are in the Reding collection (RED) as well. Other specimens are kept in the Ruffoni (RUF) and Vinçon (VIN) collections.

\section{TAXONOMY}

\section{Nemoura aprutiana Vinçon \& Ruffoni sp. nov.}

(Figures 1, 2, 3a, 4a, 5a, 6, 10, 11)

urn:1sid:zoobank.org:act:FE79EE6C-859C-4A1C-9D9900FFDDAF3A0F

Morphological diagnosis. This species is characterized in the male by the 2 apical sclerites of the epiproct that are wide and short, shieldshaped, in contrast with the other species of the same group occurring in Italy. The female cannot be separated with confidence.

Type material. Holotype male: Italy, Abruzzi, Val Fondillo, Tornareccia spring, 1110-1120 m, 41.771N, 13.857E, 20.05.2021 (catalogue number: GBIFCH00970961) (Fig. 10). Paratypes: same locality and date, $8{ }^{\lambda}, 8+$, leg. G. Vinçon
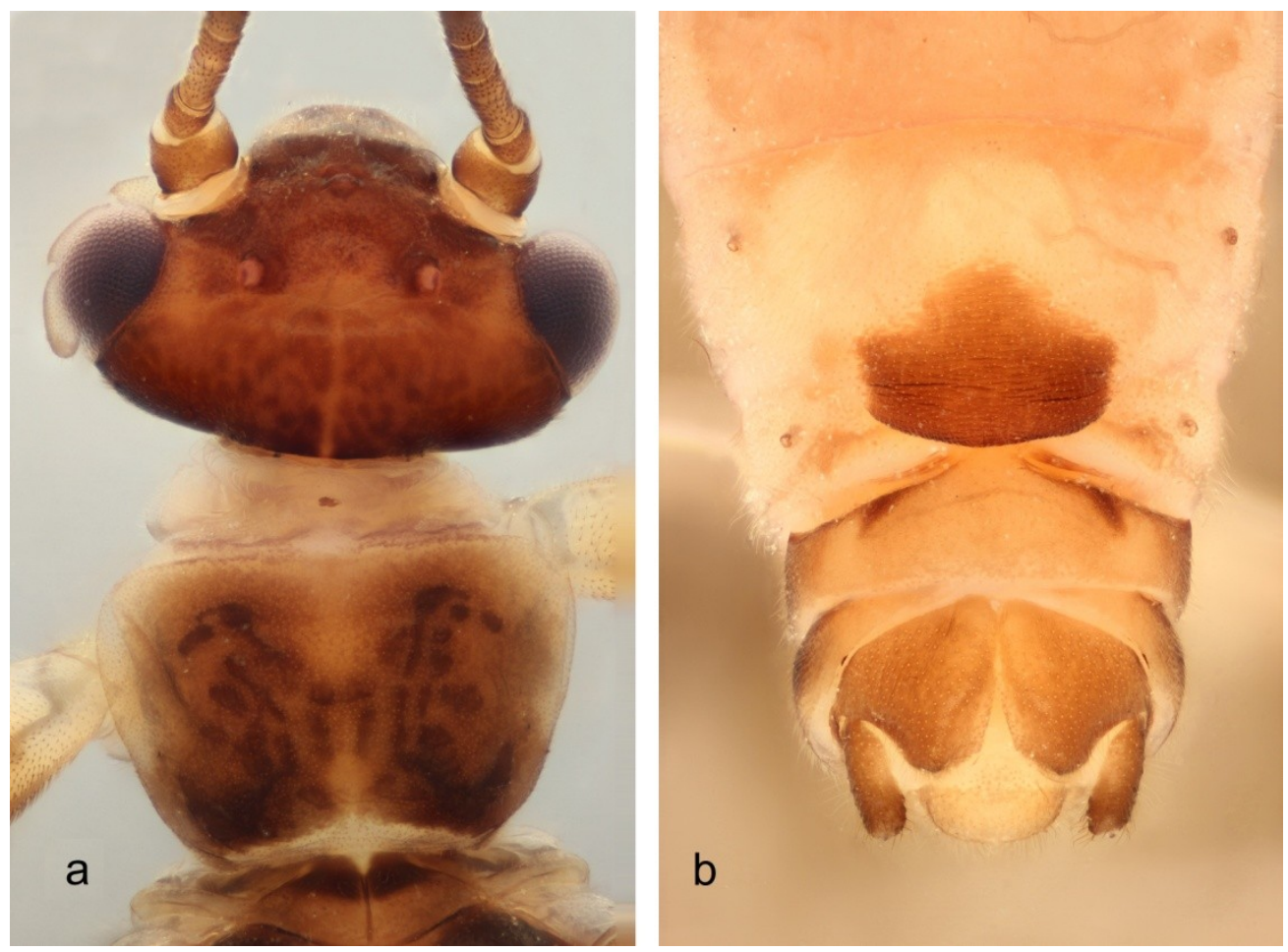

Figure 1. $N$. aprutiana sp. nov.: $\mathrm{a}=$ head and pronotum, $\mathrm{b}=$ female abdomen in ventral view. 

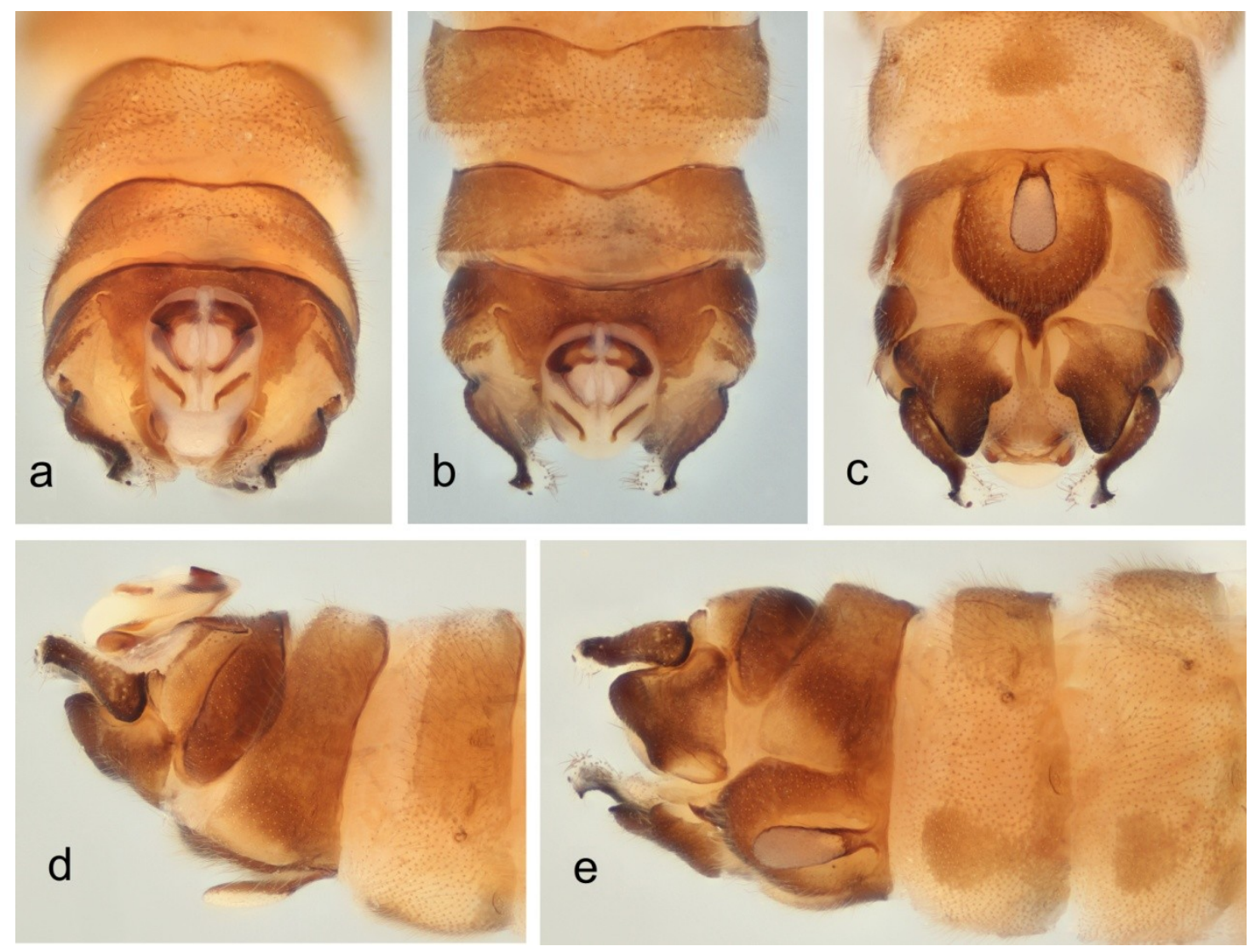

Figure 2. $N$. aprutiana sp. nov. male genitalia: $\mathrm{a}=$ dorsal view, $\mathrm{b}=$ dorsal view with tip of epiproct slightly raised, $\mathrm{c}=$ ventral view, $\mathrm{d}=$ lateral view, $\mathrm{e}=$ oblique ventral view.

(deposited in the MZL) (catalogue number: GBIFCH00970962), other paratypes: same locality and date, $6 \hat{0}, 5$, leg. G. Vinçon (RED); Latium, Abruzzi Massif, Prati di Mezzo, above Fontitune, spring and brook along the torrent, $1560 \mathrm{~m}, 41.653 \mathrm{~N}, 13.936 \mathrm{E}, 10.06 .2020,2 \hat{\jmath}, 3$, leg. G. Vinçon (RED) (Fig. 11).

Additional material. Italy, Latium, Abruzzi Massif, Prati di Mezzo, above Fontitune, spring and brooklet along the torrent, $1560 \mathrm{~m}, 41.653 \mathrm{~N}$, 13.936E, 10.06.2020, 6ㅇ (VIN), same locality, 21.05.2021, 15 $\hat{\jmath}, 14 q$ (VIN), same locality, 12.06.2021, $4 \hat{\jmath}, 5$ ㅇ (VIN); Italy, Latium, Abruzzi mountains, Vallerotonda, spring of the Collelungo River, $1480 \mathrm{~m}, 41.628 \mathrm{~N}, 13.978 \mathrm{E}, 2.07 .2020,2 \widehat{O}$, 89 (VIN); Italy, Abruzzi, Val Fondillo, Tornareccia spring, $1110-1120 \mathrm{~m}, 41.771 \mathrm{~N}, 13.857 \mathrm{E}$, 13.06.2021, 2ㅊํ, 5 우 (VIN).
Description. A large-sized Nemoura species. Males and females macropterous. Body length of males 6.5 to $8.1 \mathrm{~mm}$, females 8.0 to $12.2 \mathrm{~mm}$, forewing length of males 7.1 to 8.2 , females 8.5 to $12.1 \mathrm{~mm}$. General color light brown; head dark brown, except light brown between the composed eye and the ocellus; dark granulations on the occiput (Fig. 1a); antennae light brown; pronotum with dark brown marks (Fig. 1a); legs light brown. Forewings smoky brown.

Male genitalia. Tergite 8 sclerotized on its lateral edges and with median membranous field; anterior margin not interrupted and slightly curved backwards; posterior margin medially interrupted; tergite 9 similar with few scattered spines in one row on posterior edge (Figs. 2a-b). Hypoproct terminated by a short finger-shaped expansion (Fig. 2c). Ventral vesicle racket-shaped (Fig. 2c). Inner lobe of paraprocts well visible, 

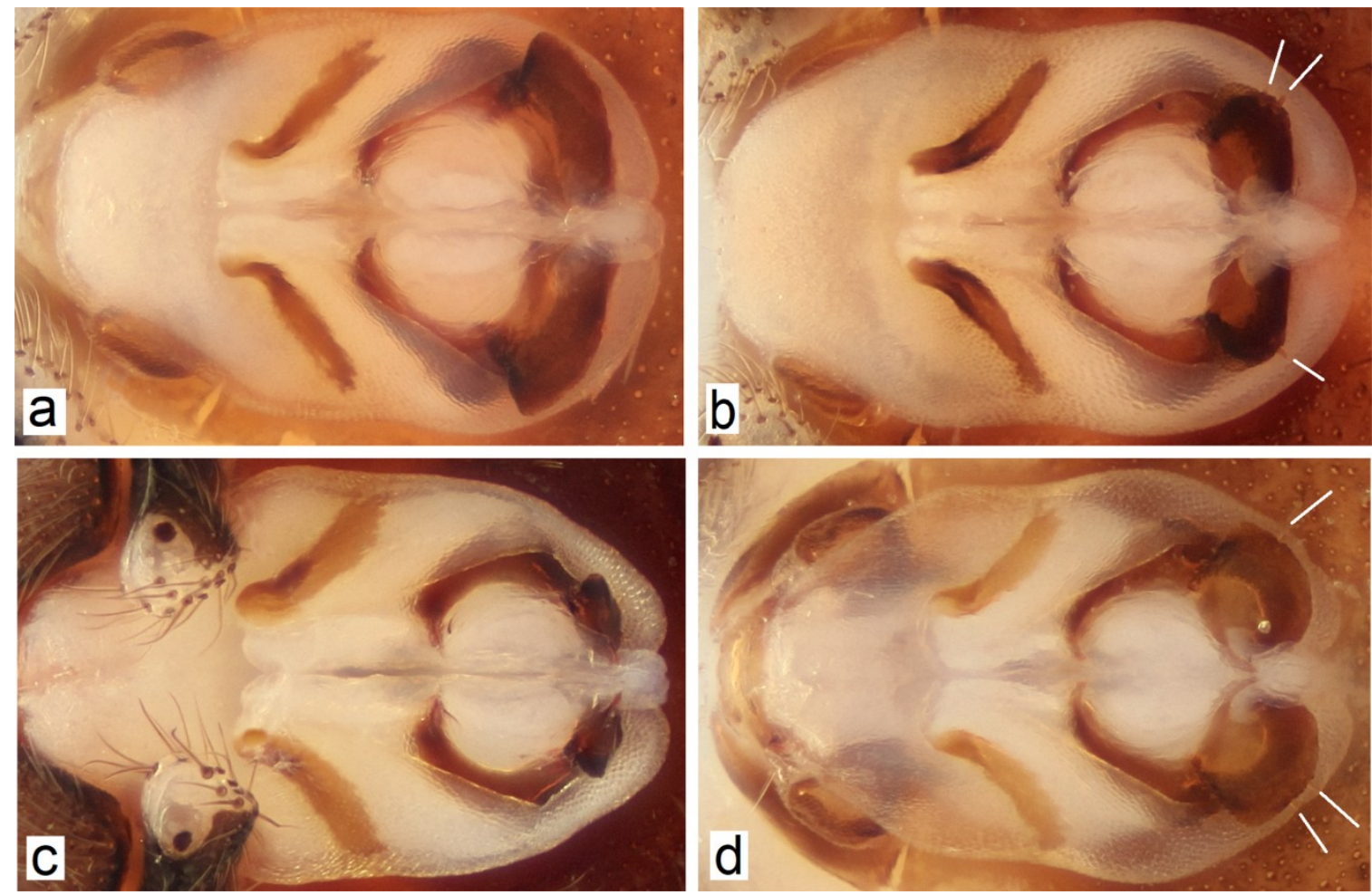

Figure 3. Epiproct in dorsal view: $\mathrm{a}=N$. aprutiana $\mathrm{sp}$. nov., $\mathrm{b}=N$. hesperiae, $\mathrm{c}=N$. lucana. $\mathrm{d}=N$. palliventris (spines shown by white lines).

thin and long, projecting backwards on each side of the hypoproct expansion. Outer lobe of paraproct subtriangular, tapering toward the tip, and with an inner pre-apical constriction near midlength (Fig. 2c); cercus with rounded base, sclerotized on its outer edge and membranous on its inner edge; cercus apex looking like a bird's head, globular, membranous and covered with long hairs on its inner part and with a strong sclerotized beak (or hook) on its outer part; the sclerotized part extends on nearly one third of the cercus head while the membranous part covers the two remaining thirds; the beak is wide and stout hardly extending on nearly a fourth of the width of the cercus head; the trace of a vestigial second segment is visible on the membranous field of the cercus head, looking like a dark spot (Figs. 2a-c); in lateral view, the cercus is slightly curved downwards (Fig. 2d), while in oblique ventral view it appears nearly rectilinear with sinuous edges (Fig. 2e). Epiproct slightly longer than wide, subrectangular with its tip rounded in dorsal view
(Figs. 3a, 4a). Arms of the ventral sclerite dorsally forming a ring with: -2 basal branches (named 'bb' in Fig. 4a), rectilinear and partly hidden by a membranous fold, -2 inner branches ('ib', Fig. 4a), finger shaped, oriented toward the median part of the epiproct and almost touching each other medially, -2 apical branches (also called apical sclerites) ('ab', Fig. 4a), wide and short, shield-shaped, and separated by a rounded membranous vesicle. In Nemoura, the sperm passes through this vesicle, guided by the apical sclerites. In lateral view, the apical sclerites looking like plates, are clearly protruding upwards and sloping downwards toward the apex (Fig. 5a), one or two spines are visible on the inner edge (Fig. 5a, red lines); the two basal ridges of the ventral sclerite of the epiproct parallel, bearing a row of several long spines (around 10).

Female. Pregenital plate of sternite 7 dark brown, protruding on sternite 8 and reaching sternite 9 medially; its posterior edge is slightly convex (Fig. 1b). Paraprocts subtriangular and cerci nearly twice as long as wide (Fig. 1b). 

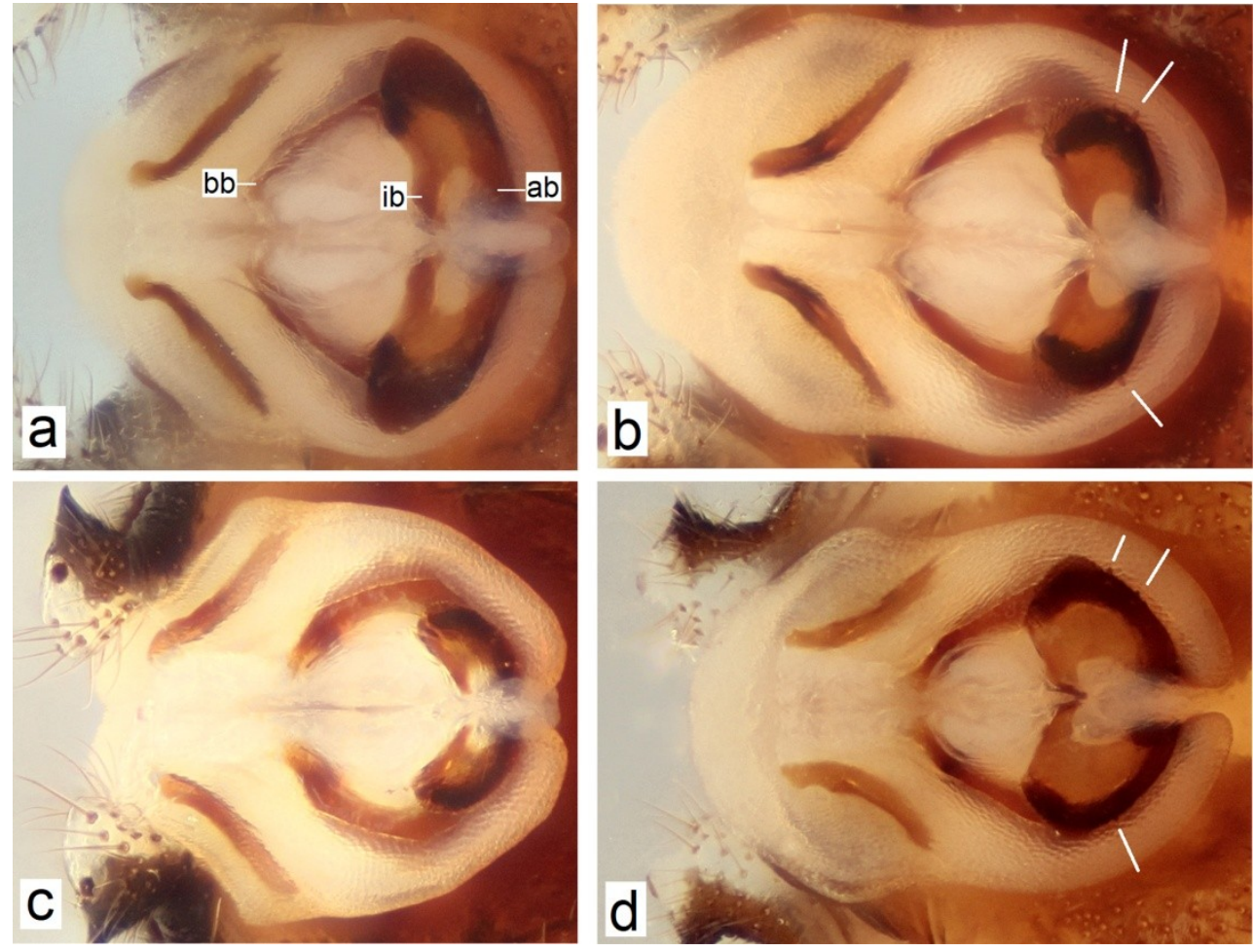

Figure 4. Epiproct in dorsal view with its tip slightly raised (nearly $30^{\circ}$ ): $\mathrm{a}=N$. aprutiana sp. nov., $\mathrm{b}=N$. hesperiae, $\mathrm{c}=N$. lucana. $\mathrm{d}=N$. palliventris $(\mathrm{bb}=$ basal branch, $\mathrm{ib}=$ inner branch, $\mathrm{ab}=$ apical branch $(=$ apical sclerite $)$. (spines shown by white lines).
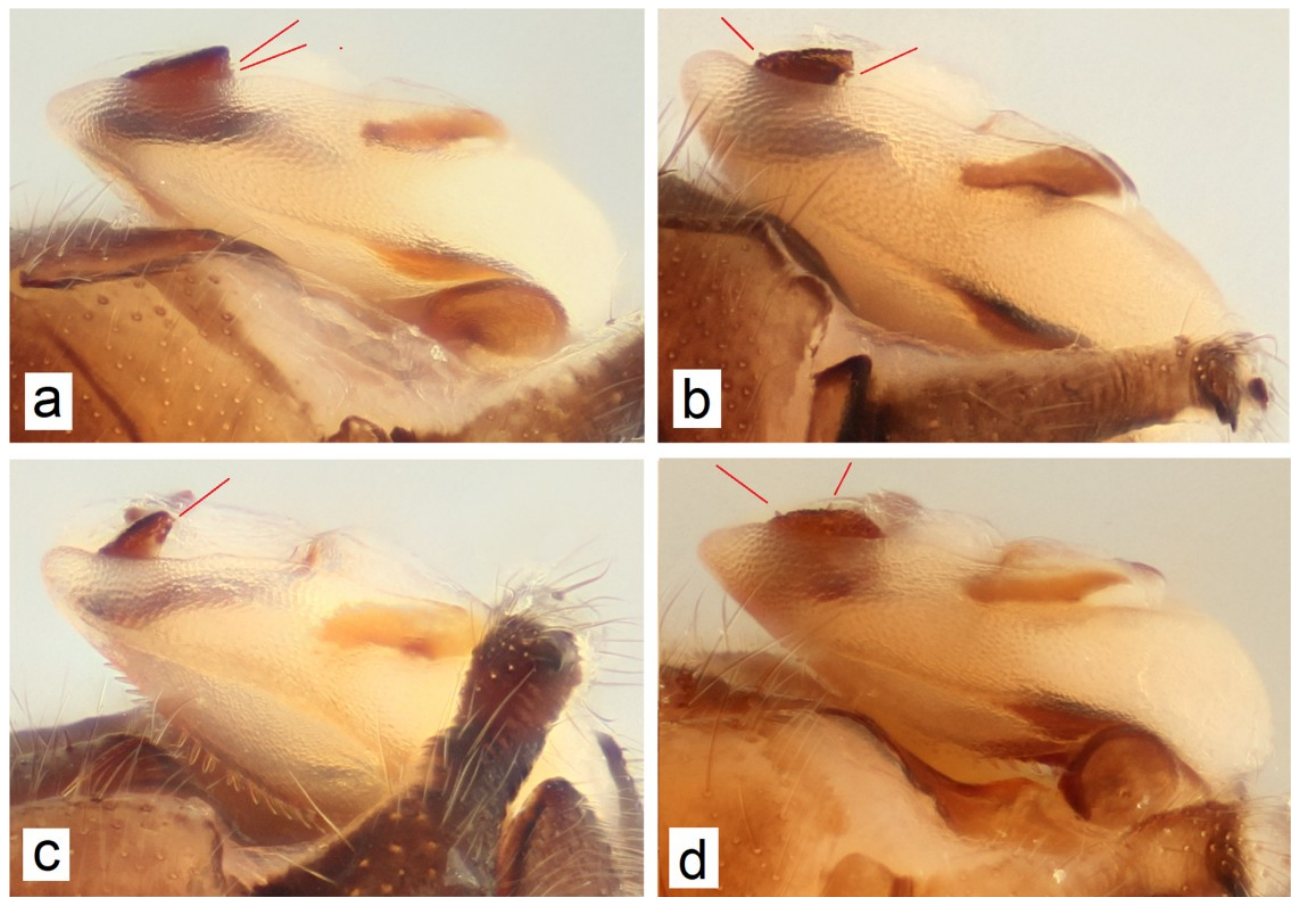

Figure 5. Epiproct in lateral view: $\mathrm{a}=N$. aprutiana $\mathrm{sp} . \mathrm{n} ., \mathrm{b}=N$. hesperiae, $\mathrm{c}=N$. lucana $. \mathrm{d}=N$. palliventris (spines shown by red lines). 
Morphological affinities. Males. This sister species of N. hesperiae, N. lucana and N. palliventris differs by the shape of the two apical sclerites of the epiproct (named ' $a b$ ' in Fig. 4a); they are wide and short in $N$. aprutiana sp. nov. (Figs. 3a, 4a), more rounded and with one or two lateral spines in $N$. hesperiae (Figs. 3b, $4 \mathrm{~b}$ ) and in $N$. palliventris (Figs. 3d, 4d) and much smaller in $N$. lucana (Figs. $3 \mathrm{c}, 4 \mathrm{c}$ ). Moreover, $N$. aprutiana sp. nov. is also separable by the outer edge of the apical sclerites forming a blunt angle (Fig. 3a) while it is rounded in $N$. hesperiae (Fig. 3b) and in N. palliventris (Fig. 3d). It is also related, but to a lesser degree, to the Alpine species $N$. obtusa Ris, 1902, from which it however, clearly differs by the shape of the male cercus, twisted in lateral view and with truncate apex in $N$. obtusa (cf. Kis 1974, Figs. 79a, c-d). Moreover, according to the shape of the apical sclerites of the epiproct, $N$. aprutiana sp. nov. looks like three other species: N. erratica Claassen, 1936, occurring in western Europe, N. pseudoerratica Vinçon \& Pardo, 2003 occurring in the Pyrenees and Northern Spain and $N$. uncinata Despax, 1934, with a central and south European distribution and also present in the Italian Alps, but it clearly differs from them by the presence of an inner branch on the apical sclerite of the epiproct (Fig. 4a, named 'ib') that is lacking in $N$. erratica or $N$. pseudoerratica (Vinçon \& Pardo 2003, Figs. 1a, 2a) and in N. uncinata (cf. Kis 1974, Fig. 82c, sub. nom. N. fulviceps).

Females. Females of Nemoura aprutiana sp. nov. are actually not separable with confidence from those of $N$. hesperiae, N. lucana and N. palliventris and from those of many other congeners; their identification should be confirmed by male capture.

Distribution area and biogeographical notes. $N$. aprutiana sp. nov. is presently known only from three localities on the southwestern edge of the Abruzzi Massif (Figs. 6, 10, 11) and is probably a steno-endemic species of this region. It is a crenophilic species with a flight period spanning over spring and early summer (V-VII).

Derivatio nominis. Nemoura aprutiana sp. nov. is named after the region in which it occurs, namely the Abruzzi region (latinized as "Aprutium"). The epithet is to be treated as a Latin adjective, feminine in gender combined with $\mathrm{Ne}$ moura.

\section{Nemoura hesperiae Consiglio, 1960}

(Figures 3b, 4b, 5b, 6, 7a-d)

Type locality. Italy: Abruzzi, Lecce del Marsi, Le Prata di Lecce, 1540 m, 22.06.1954 (Consiglio coll.).

Previous data. Italy: Ligurian Apennines: (Ravizza 1974). Emilia-Romagna (Consiglio 1960, Fochetti \& Campadelli, 1988, 1991); Marche (Fochetti \& Nicolai 1987); (Consiglio 1958 sub nom. N. erratica, Consiglio 1967); Lazio (Nicolai \& Fochetti 1983); Abruzzi (Consiglio 1958 sub nom. N. erratica, Consiglio 1967, Nicolai 1983, Nicolai, Fochetti \& Dell'Agata 1988); Sicily (Ravizza \& Gerecke 1991).

New data. Italy: Toscana: above Vinca: br. and spr., $1000 \mathrm{~m}, 44.127 \mathrm{~N}, 10.175 \mathrm{E}, 2.04 .2017$, 4ð (VIN); $1200-1300 \mathrm{~m}$, br. and spr., $44.117 \mathrm{~N}$, 10.175E, 2.04.2017, 2犬े, 1 q (VIN); Passo del Cerreto: Crocetta Hamlet, 1280 m, spr., 44.2975 N, 10.2268E, 18.05.2021, 10, 3 (VIN); Passo del Cerreto: $1400 \mathrm{~m}$, br. and spr., $44.2895 \mathrm{~N}$, 10.2275E, 18.05.2021, $1 \delta^{\lambda} ; 1420-1480 \mathrm{~m}$, torrent, $44.288 \mathrm{~N}, 10.227 \mathrm{E}, 18.05 .2021,10{ }^{\lambda} ; 11.06$. 2021, 2ð, 15우 (VIN); below Passo del Cerreto: «La Gabellina», $950 \mathrm{~m}$, spr., 44.3175N, 10.238E, 18.05.2021, 6 ${ }^{\lambda}$ (VIN); Passo della Pradarena: $1570 \mathrm{~m}$, spr. and br., $44.2876 \mathrm{~N}, 10.3008 \mathrm{E}, 18.05$. 2021, 1今̄, 2 + (VIN); 1570 m, spr., 44.2817N,

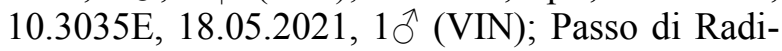
ci: spr., $1480 \mathrm{~m}, 44.2063 \mathrm{~N}, 10.4913 \mathrm{E}, 18.05$. 2021, $8 \hat{\jmath}$ (VIN); Val di Luce: $1600-1650 \mathrm{~m}$, br., $44.123 \mathrm{~N}, 10.628 \mathrm{E}, 7.06 .2020,10^{\uparrow} ; 1560-1600 \mathrm{~m}$, spr. and br., $44.131 \mathrm{~N}, 10.628 \mathrm{E}, 19.05 .2021,4{ }^{\top}$; $1380 \mathrm{~m}$, spr. and br., 44.144N, 10.632E, 19.05 .

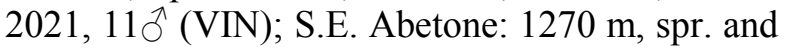
br., 44.128N, 10.675E, 19.05.2021, 1ठ; $1340 \mathrm{~m}$,

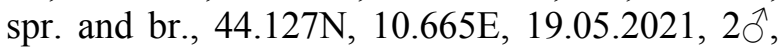
6 ㅇ (VIN); above Reggello: spr. and br., $800 \mathrm{~m}$, $43.691 \mathrm{~N}, 11.575 \mathrm{E}, 8.06 .2020,1 \mathrm{O}^{\top}$; 19.05.2021, $2{ }^{\circ}, 18$; ; spr. $920 \mathrm{~m}, 43.6906 \mathrm{~N}, 11.582 \mathrm{E}, 19.05$. 


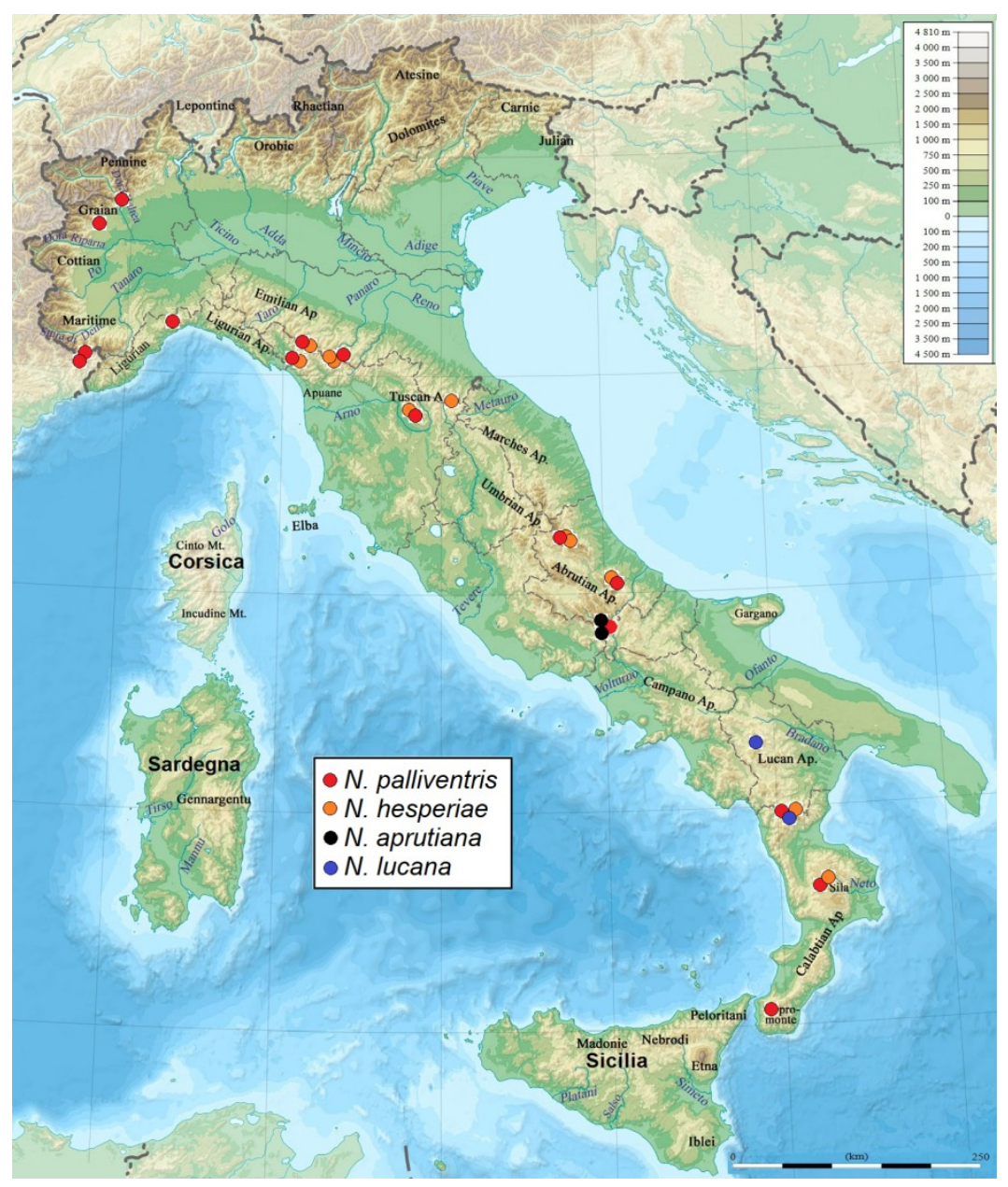

Figure 6. Distribution area of $N$. palliventris, $N$. hesperiae, $N$. aprutiana sp. nov. and $N$. lucana in the Italian region (listing only specimens confirmed by our own data and the holotype of $N$. lucana. The distribution of $N$. hesperiae and N. palliventris in Sicily is not given since it requires checking several collections that is outside the scope of this project)

2021, 5ึ̂, 9우 (VIN); Pratomagno: br. and spr., $1180 \mathrm{~m}, 43.613 \mathrm{~N}, 11.688 \mathrm{E}, 20.05 .2021,1 \mathrm{O}^{\top}, 9$; spr., $1400-1450 \mathrm{~m}, 43.652 \mathrm{~N}, 11.649 \mathrm{E}, 20.05$. 2021, 50, 8 ㅇ (VIN). Emilie-Romagna: West passo di Cerreto: spr. of Secchia R., $1620 \mathrm{~m}$, 44.322N, 10.192E, 30.06.2020, 10, 1 우 (VIN); below Passo del Cerreto: spr. below the capture, Secchia tributary, $1200 \mathrm{~m}, 44.305 \mathrm{~N}, 10.226 \mathrm{E}$, 2.04.2017, $3 \hat{\circ}, 1$ ( $(\mathrm{VIN})$; Passo delle Radici: N. slope, $1500 \mathrm{~m}$, spring, 44.194N, 10.502E, 4.06. 2020, 10, 11 ( (VIN); Balze: Tevere spr., 1300 m, 43.787N, 12.075E, 3.04.2015, 1 Ð $^{\text {(VIN). } A b-}$ ruzzi: Prati di Tivo: spring and brook below the fountain, $1550-1580 \mathrm{~m}, 42.502 \mathrm{~N}, 13.573 \mathrm{E}, 14.06$. $2020,14{ }^{\lambda}, 2$ 早; $1700-1740 \mathrm{~m}, 42.495 \mathrm{~N}, 13.579 \mathrm{E}$,

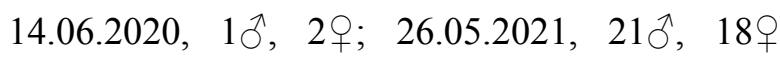
(VIN); Prati di Tivo: $1320 \mathrm{~m}, 42.515 \mathrm{~N}, 13.573 \mathrm{E}$, 26.05.2021, 4^, 6 ㅇ (VIN); Arno spr., 1450-1500

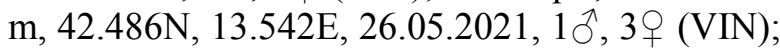
Casale San Nicola, above Montario al Vomano, $1000 \mathrm{~m}$, br. and spr., $42.478 \mathrm{~N}, 13.599 \mathrm{E}, 4.04$. 2015, 7 $\hat{\jmath}, 3$ ㅇ (VIN); Maiella: top of San Spirito Valley, below the capture, spr. and br., $1720 \mathrm{~m}$, $42.1664 \mathrm{~N}, 14.118 \mathrm{E}, 2.07 .2020,2 \hat{\gamma}, 19$ (VIN);

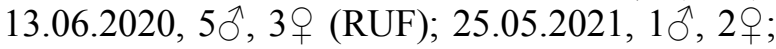
San Spirito Valley, large sliding flagstones, $1530 \mathrm{~m}, 42.166 \mathrm{~N}, 14.113 \mathrm{E}, 2.07 .2020,4{ }^{\top}, 1$; 25.05.2021, $9 \AA, 9$ 으 (VIN); N. Maiella, Foro valley, spr., $1200 \mathrm{~m}, 42.1806 \mathrm{~N}, 14.1252 \mathrm{E}, 25.05$. 2021, $2 \hat{O}^{\hat{~}}$ (VIN). Basilicata: Pollino, 1650 m, spr. 

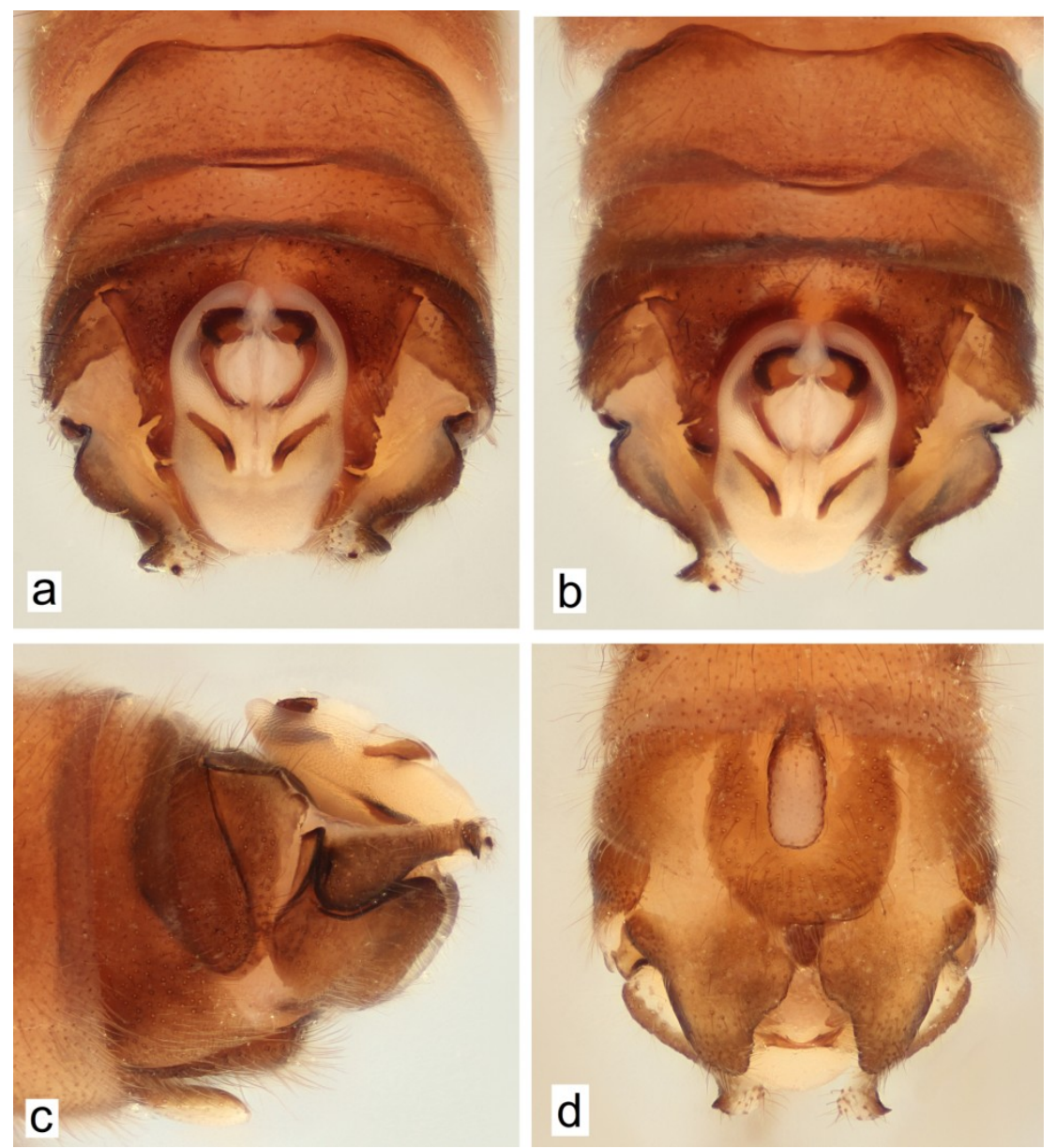

Figure 7. $N$. hesperiae, male genitalia: $\mathrm{a}=$ dorsal view, $\mathrm{b}=$ dorsal view with tip of epiproct slightly raised, $\mathrm{c}=$ lateral view, $\mathrm{d}=$ ventral view (specimen from the Maiella Massif, $1720 \mathrm{~m}, 42.1664 \mathrm{~N}, 14.118 \mathrm{E}, 13.06 .2020$ ).

and br., 39.922N, 16.187E, 24.05.2021, 1ठ, 3 + (VIN). Calabria: Sila grande, many lateral springs, $1720 \mathrm{~m}, 39.2915 \mathrm{~N}, 16.439 \mathrm{E}, 22.05 .2021$, $1 \hat{O}^{\widehat{N}}(\mathrm{VIN})$.

Description of male genitalia (Figs. 3b, 4b, 5b, $6,7 \mathrm{a}-\mathrm{d})$. Outer lobe of paraproct subtriangular with an inner concavity near mid-length (Fig. 7d); cercus with rounded base and globular apex forming a strong beak outward, and inward looking like a rounded membranous head covered with long hairs and bearing a vestigial second segment with dark sclerotized spot nearly looking like a small tooth (Figs. 7a-b, 7d); in lateral view, the cercus is slightly curved downwards (Fig. 7c). Epiproct bearing two strong apical sclerites separated by a globular vesicle (Figs. 3b, $4 b$ ); each sclerite is half circle shaped and bears one or two lateral spines visible in dorsal view (Fig. 4b, white lines) and one spine on the inner edge visible in lateral view (Fig. 5b, red lines); the inner branch is short, oriented toward the median part of the epiproct and separated from the apical sclerite by a rounded membranous field (Fig. 4b). In lateral view, the apical sclerites of the epiproct are clearly protruding upwards and sloping downwards, toward the apex (Fig. 5b); the two basal ridges of the ventral sclerite of the epiproct bear a row of several long spines.

Affinities. N. hesperiae is a sister species of $N$. aprutiana sp. nov. from which it differs by having more rounded apical sclerites of the epiproct in dorsal view, less developed inner branches of the 

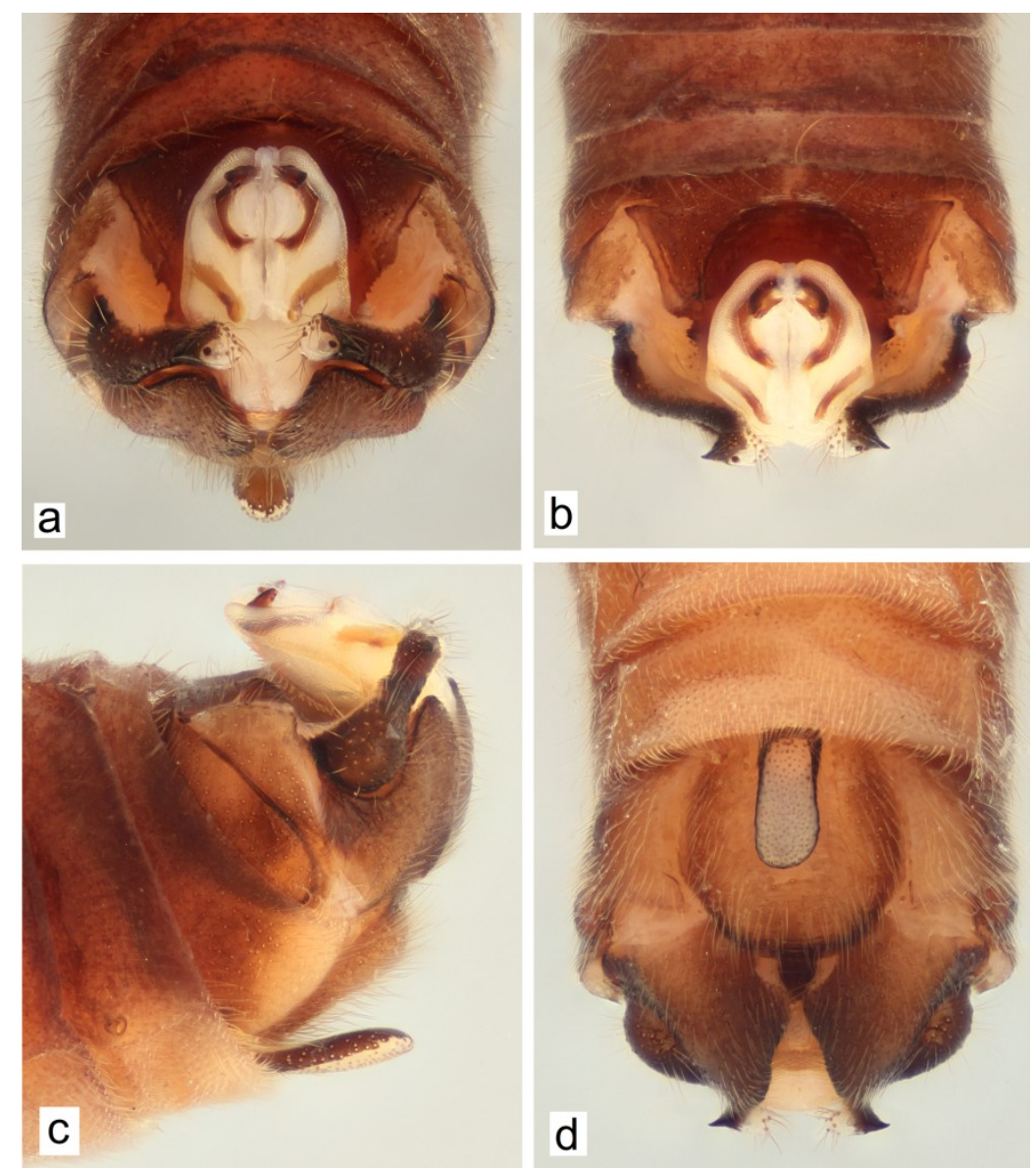

Figure 8. $N$. lucana, male genitalia: $\mathrm{a}=$ dorsal view, $\mathrm{b}=$ dorsal view with tip of epiproct slightly raised, $\mathrm{c}=$ lateral view, $\mathrm{d}=$ ventral view (specimen from Pollino, 1600-1650 m, spr. + br., 39.916N, 16.177E, 10.06.2020).

epiproct and one or two lateral spines on the apical sclerite of the epiproct that are lacking in $N$. aprutiana sp. nov. (compare Figs. 3a, 4a with Figs. $3 b, 4 b)$. It is separable from $N$. lucana that has smaller apical sclerites (Figs. 3c, 4c) and from $N$. palliventris with much larger apical sclerites (Fig. 4d).

Distribution area and biogeographical notes. $N$. hesperiae has a wide distribution area in the Italian Peninsula from the Ligurian Apennines up to Calabria (Aspromonte) and it also occurs in Sicily, though we don't depict it on the map (Fig. 6) since we did not check any Sicilian specimens.

The species has a wide altitudinal range (570$1740 \mathrm{~m}$ ) and inhabits preferentially crenal and hypocrenal biotopes (orophilic and crenophilic species). The flight period is in spring and early summer (IV-VII).

\section{Nemoura lucana Nicolai \& Fochetti, 1991}

(Figures 3c, 4c, 5c, 6, 8a-d).

Type locality. Italy: Basilicata, small tributary of Riofreddo Stream (1100 m) near Rifreddo (Potenza), 21.05.1984 (Nicolai \& Fochetti 1991).

Previous data. Until now, this species was reported only from its type locality, but has recently been found also in the Pollino Massif (Vinçon, Ravizza \& Reding 2022).

Material examined. Italy: Basilicata: Pollino, 1600-1650 m, spr. + br., 39.916N, 16.177E, 10 . 06.2020, 1万우 (RUF). 

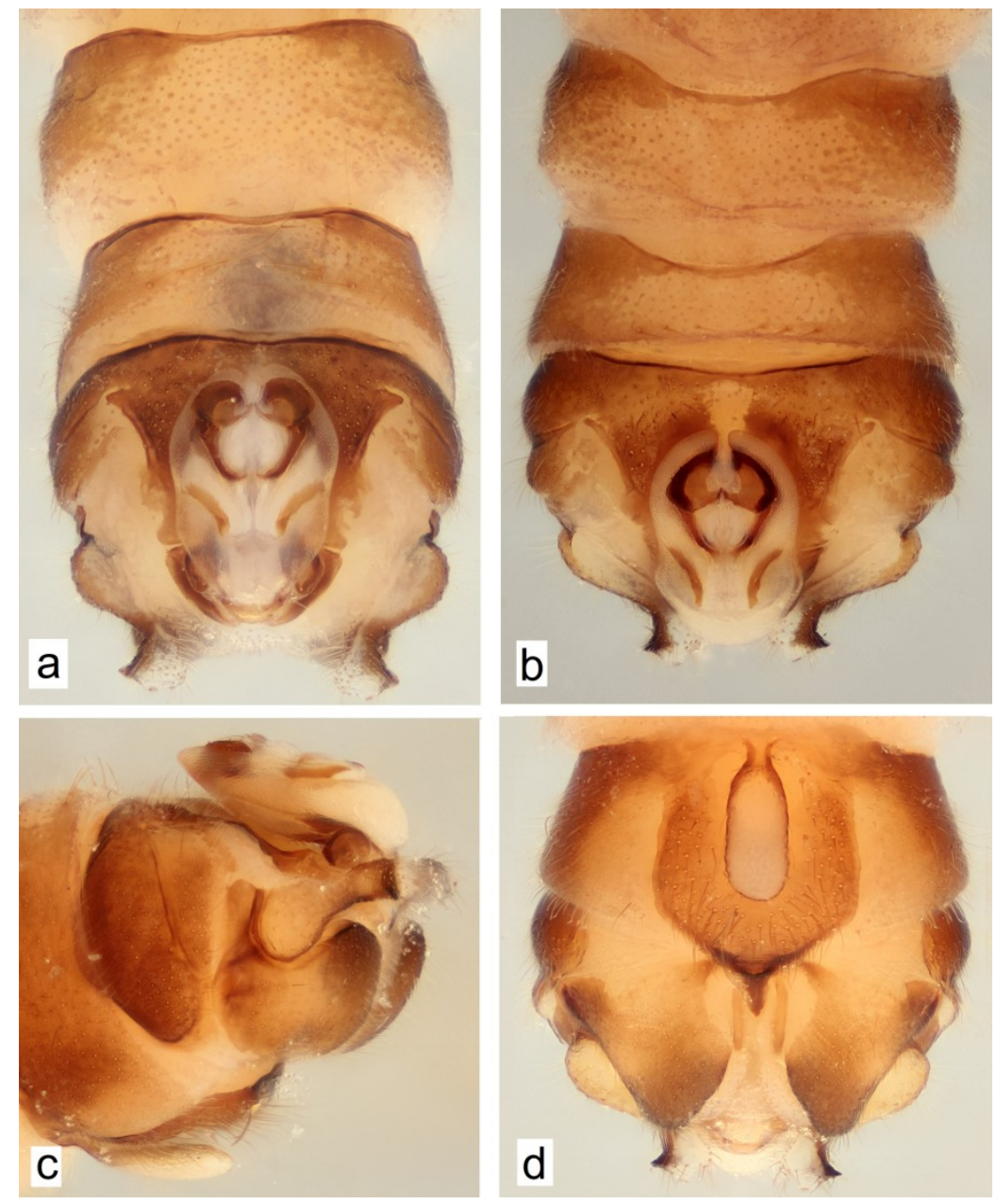

Figure 9. $N$. palliventris, male genitali: $\mathrm{a}=$ dorsal view, $\mathrm{b}=$ dorsal view with tip of epiproct slightly raised, $\mathrm{c}=$ lateral view, $\mathrm{d}=$ ventral view (specimen from the Sila Massif, $1580-1650 \mathrm{~m}, 39.32 \mathrm{~N}, 16.401 \mathrm{E}, 11.06 .2020$ ).

Description of male genitalia. Outer lobe of paraproct subtriangular with a very slight inner concavity near mid-length (Fig. 8d); cercus with rounded base and globular apex forming a strong beak outward, and inward looking like a rounded membranous head covered with long hairs and bearing a vestigial second segment with dark spot (Figs. 8a-b); in lateral view, the cercus is nearly rectilinear (Fig. 8c). Epiproct: the two apical sclerites very short, nearly rounded, shield-shaped, and separated by a membranous vesicle, in dorsal view (Figs. 3c, 4c); in lateral view, they are narrow and strongly raised (Fig. $5 \mathrm{c}$ ) and carrying one or two short spines on their inner edge (Fig. 5c, red line). The inner branches are very short, oriented toward the median part of the epiproct and getting thinner toward their apex (Fig. 4c). The two basal ridges of the ventral sclerite of the epiproct bear a row of several long spines.

Affinities. $N$. lucana is close to $N$. hesperiae and to a lesser degree to $N$. aprutiana sp. nov. and $N$. palliventris. it mainly differs from both of them by the smaller apical sclerite of the epiproct in dorsal and lateral views (Figs. 3, 4, 5).

Distribution area and biogeographical notes. $N$. lucana is known only from high altitude brooklets and springs in the southern Apennines, from Potenza to the Pollino Mount (Basilicata) (1100$1650 \mathrm{~m}$ ) (Fig. 6). Its flight period is in spring (VVI). 


\section{Nemoura palliventris Aubert, 1953}

(Figures 3d, 4d, 5d, 6, 9a-d)

Nemoura silana Aubert, 1953, Syn. fide Aubert (1958).

Type locality: Italy: Calabria, Sila, Mucone, 19.05.1952 (Aubert 1953).

Previous data. Switzerland: Lepontine PreAlps, Tisino (Aubert et al. 1996). Italy: Cottian Alps (Ravizza \& Ravizza Dematteis 1986, Ravizza Dematteis \& Ravizza 1988). Ligurian Alps (Consiglio 1967, Ravizza \& Ravizza Dematteis 1977 sub. nom. N. hesperiae). France: Maritime Alps (Aubert 1986, Vinçon 1996). Italy: Ligurian Apennines (Ravizza 1974 sub. nom. N. hesperiae, Ravizza 1976 sub. nom. N. hesperiae, Ravizza \& Ravizza Dematteis 1983). Emilia-Romagna (Fochetti \& Campadelli 1991). Marche (Aubert 1956b, Fochetti \& Nicolai 1987). Lazio (Nicolai \& Fochetti 1983). Abruzzi (Consiglio 1958). Campania (Nicolai \& Fochetti 1991). Basilicata (Aubert 1953, 1958, Nicolai \& Fochetti 1991). Calabria (Aubert 1953, ex parte sub. nom. N. silana, Nicolai \& Fochetti 1991). Sicily (Aubert 1957, Consiglio 1961, Ravizza \& Gerecke 1991).

New data. Italy: Pennine Alps: Aosta Valley, above Settimo-Vitonne, tor., $450 \mathrm{~m}, 45.554 \mathrm{~N}$, 7.839E, 31.03.2000, 60 (VIN). Graian Alps: below Viu, br., $600 \mathrm{~m}, 45.235 \mathrm{~N}, 7.432 \mathrm{E}, 1.04$. 2000, 3 $\widehat{\partial}, 1$ 우 (VIN). Ligurian Apennines: Beigua Mount, spr. and br., $1000 \mathrm{~m}, 44.428 \mathrm{~N}, 8.543 \mathrm{E}$, 1.04.2017, 1 $\widehat{\gamma}, 3$ ㅇ (VIN); Pianpaludo, above Veirera, SW Urbe, $950 \mathrm{~m}, 44.458 \mathrm{~N}, 8.553 \mathrm{E}, 7.04$. 2015, $1 \sigma^{\lambda}$ (VIN). Toscana: Apuane mountains: road to Vinca, big resurgence above the river, 330 $\mathrm{m}, 44.15 \mathrm{~N}, 10.135 \mathrm{E}, 5.04 .2015,8 \hat{\jmath}, 1$ \% 2.04 . 2017, 3 1 , 1 ( (VIN); road to Vinca, br. and spr., $500 \mathrm{~m}, 44.14 \mathrm{~N}, 10.146 \mathrm{E}, 5.04 .2015,2 \hat{0}$, 3우 (VIN); above Vinca, br. and spr., $1200-1300 \mathrm{~m}$, $44.117 \mathrm{~N}, 10.175 \mathrm{E}, 2.04 .2017,2 \hat{\circ}, 2$ 우 (VIN); road to Passo del Cerreto, crossroad to Sassalbo,

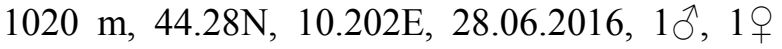
(VIN); Val di Luce, $1600-1650 \mathrm{~m}$, br., $44.123 \mathrm{~N}$, 10.628E, 7.06.2020, $1 \hat{\jmath}$ (VIN); S.E. Abetone, $1270 \mathrm{~m}$, spr. and br., $44.128 \mathrm{~N}, 10.675 \mathrm{E}, 19.05$. 2021，3 3 (VIN); SE Reggello, Pratomagno Mountains, $1300-1400 \mathrm{~m}$, br. and spr., $43.645 \mathrm{~N}$,
11.665E, 8.06.2020, 14ð, 9 (VIN). Abruzzi: Prati di Tivo, spr. and br. $1550-1580 \mathrm{~m}, 42.502 \mathrm{~N}$,

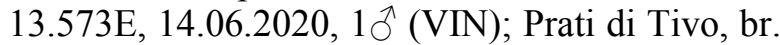
and spr., $1370 \mathrm{~m}, 42.51 \mathrm{~N}, 13.574 \mathrm{E}, 14.06 .2020$, $14{ }^{\lambda}, 8$ ㅇ (VIN); Val Fondillo, br. and spr., 1300 $\mathrm{m}, 41.749 \mathrm{~N}, 13.865 \mathrm{E}, 9.06 .2020,1 \delta^{\lambda}$ (VIN); Maiella Massif, Roccamorice, above Sanctuario Santo Spirito, spr., 1300-1400 m, 42.169N, 14.102E, 13.07.2009, 10, 3 ㅇ (VIN). Basilicata: NE Lagonegro, spr., $1350 \mathrm{~m}, 40.152 \mathrm{~N}, 15.808 \mathrm{E}$,

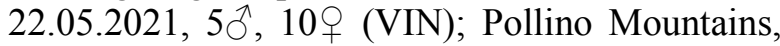
1500-1600 m, spr. and br., 39.925N, 16.177E, 11 . 06.2020, $2{ }^{\Uparrow}$ (VIN). Calabria: Sila grande: spr., 1650-1700 m, 39.32N, 16.401E, 11.06.2020, 16 , 30ㅇ 22.05.2021, 9 $\widehat{0}, 8$ ㅇ (VIN); Sila Grand: spr., $1580-1650 \mathrm{~m}, 39.32 \mathrm{~N}, 16.401 \mathrm{E}, 11.06 .2020,10 \hat{\text {, }}$, 24 ㅇ spr., $1320 \mathrm{~m}, 39.32 \mathrm{~N}, 16.385 \mathrm{E}, 22.05 .2021$, $13 \hat{O}, 18$ ( 1 (VIN); Aspromonte: $1420 \mathrm{~m}$, spr. and br., 38.144N, 15.842E, 12.06.2020, 7ð, 9ᄋ; 23. 05.2021, 18 $\lambda, 5$ 우 (VIN); below Montalto, 1760$1800 \mathrm{~m}$, spr. and br., 38.1649N, 15.916E, 23.05. 2021, 7ð, 7 ? (VIN).

Description of male genitalia (3d, 4d, 5d, 6, 9a-d). Outer lobe of paraproct subtriangular (Fig. 9d); cercus with rounded base and globular apex forming a strong beak outward, and inward looking like a rounded membranous head covered with long hairs and bearing a vestigial second segment with dark spot (Figs. 9a-b, 9d); in lateral view, the cercus is slightly bent downwards (Fig. 9c). Epiproct: the two strong apical sclerites are half circle shaped, with one or two lateral spines visible in dorsal view (Fig. 4d, white lines), and separated by a globular, transparent vesicle (Figs. $3 \mathrm{~d}, 4 \mathrm{~d}$ ); the two inner branches are oriented toward the median part of the epiproct and getting thinner toward their apex (Figs. 4d, 9b). In lateral view, the apical sclerites are very wide and clearly protruding upwards and sloping downwards, toward the apex (Fig. 5d, 9c); the two basal ridges of the ventral sclerite bear a row of several long spines.

Affinities. N. palliventris is close to $N$. hesperiae and to a lesser degree to $N$. aprutiana sp. nov. from which it differs by the larger apical sclerite of the epiproct in dorsal and lateral views (Figs. 3-5). 
Distribution area and biogeographical notes. $N$. palliventris has a wide distribution area covering the western Alps, the whole Apennine Cordillera and Sicily. It extends northwards in the French Pre-Alps up to the Vercors and Dévoluy Massifs (Vinçon 1996). It occurs in a wide altitudinal range $(200-2000 \mathrm{~m})$. The flight period is in spring and early summer, often according to the altitude (III-VII) (Vinçon, Ravizza \& Reding 2022).

Acknowledgements - We are especially grateful to Jean Paul G. Reding and Carlalberto Ravizza for the revision of the manuscript and helpful comments, and to David Murányi for his careful correction of the text.
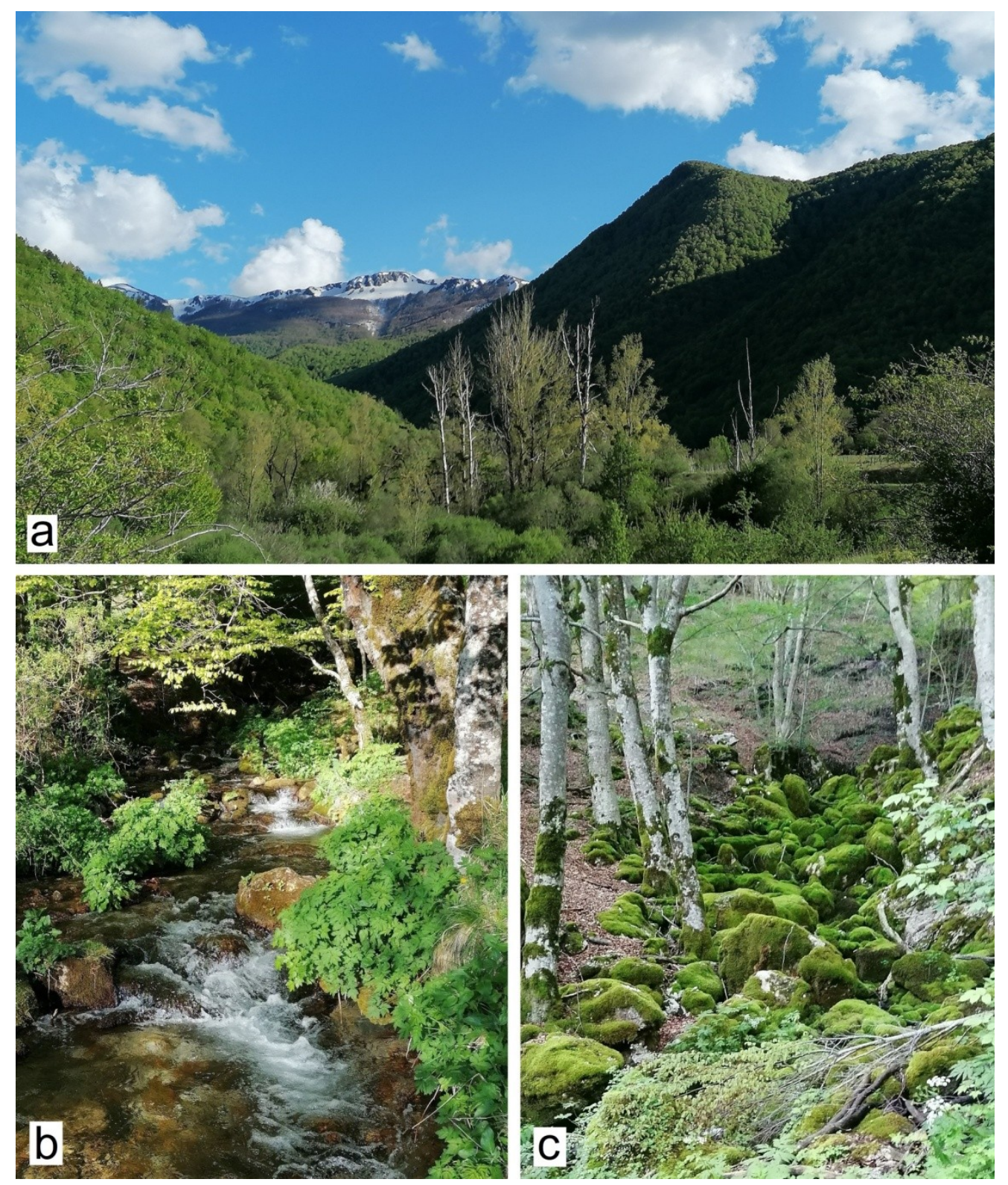

Figure 10. Collecting localities of N. aprutiana sp. nov. in the Abruzzi, Val Fondillo, 1110-1120 m, 41.771N, 13.857E: $\mathrm{a}=$ Val Fondillo, $\mathrm{b}=$ Tornareccia spring $1110 \mathrm{~m}, \mathrm{c}=$ Tornareccia spring $1120 \mathrm{~m}$. 


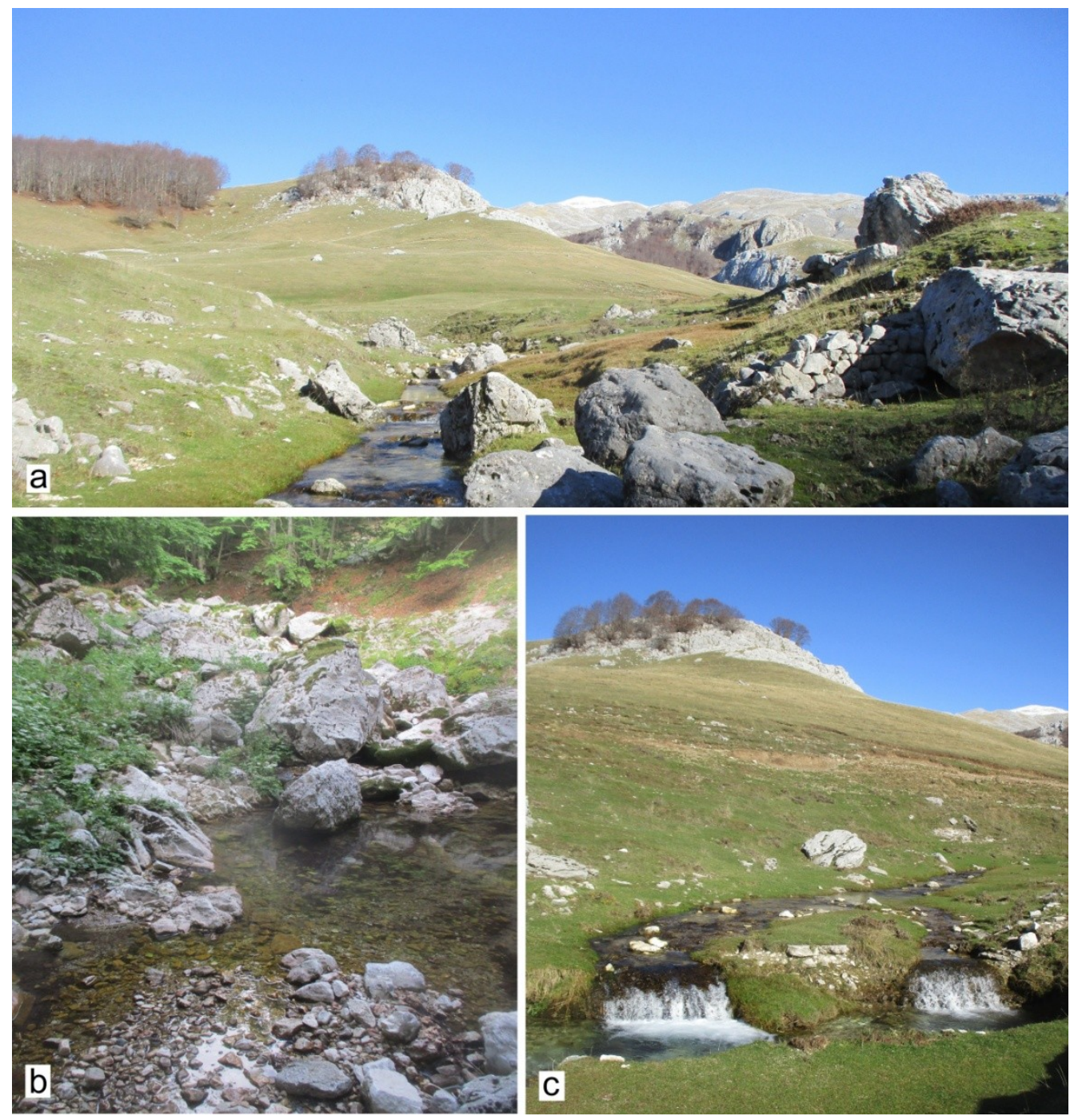

Figure 11. Collecting localities of $N$. aprutiana sp. nov. in the Abruzzi, Prati di Mezzo, 1550-1600 m, $41.653 \mathrm{~N}, 13.936 \mathrm{E}: \mathrm{a}+\mathrm{c}=$ main torrent, $\mathrm{b}=$ lateral spring at $1550 \mathrm{~m}$.

\section{REFERENCES}

Aubert, J. (1953): Contribution à l'étude des Plécoptères et des Ephéméroptères de la Calabre. Annuario dell'Istituto e museo di zoologia dell'Università di Napoli, 5(2): 1-35.

Aubert, J. (1956a): Contribution à l'étude des Plécoptères de Grèce. Bulletin de la Société entomologique Suisse, 29: 187-213.

Aubert, J, (1956b): Plécoptères des Monts Sibillins. Memorie Museo Civico Storia Naturale, Verona, 5: 89-91.

AUBERT, J. (1957):. Quelques plécoptères récoltés en
Sicile. Bulletin de la Société entomologique Suisse, 30: $175-177$.

AUBERT, J. (1958): Ricerche zoologiche sul massiccio des Pollino (Lucania-Calabria). XXV. Les Plécoptères de Calabre (Italie méridionale). Annuario dell'Istituto e museo di zoologia dell'Università di Napoli, 10(4): 1-51.

Aubert, J. (1958): Les Plécoptères de Calabre (Italie méridionale). Annuario dell'Istituto e museo di zoologia dell'Università di Napoli, 10(4): 1-51.

AUBERT, J. (1986): Les Plécoptères des Alpes Françaises. Annales de la Société Entomologique de France, 22(1): 81-104. 
Aubert, J., Aubert, C.E., Ravizza, C. \& Ravizza DEMATTEIS, E. (1996): Les Plécoptères du canton du Tessin, des vals de Mesolcina et de Calanca (canton des Grisons). Bulletin de la Société entomologique Suisse, 69: 9-40.

BAUMANN, R.W. (1975): Revision of the stonefly family Nemouridae (Plecoptera): A study of the world fauna at the generic level. Smithsonian contributions to zoology, No. 211, 74 pp. doi: $\underline{10.5479 / \text { si.00810282.211 }}$

DESPAX, R. (1934): Plécoptères pyrénéens VIII. Étude et description de quelques formes de Nemoures apparentées à Nemura marginata (Pict.) Klap. Bulletin de la Société d'Histoire Naturelle de Toulouse, 66(2): 255-270.

Consiglio, C. (1958): Plecotteri dei Monti Picentini. Memorie Museo Civico Storia Naturale, Verona, 6: 327-331.

Consiglio, C. (1960): Fauna di Romagna (Collezioni Zangheri). Plecotteri. Memorie della Società Entomologica Italiana, 39: 36-40.

Consiglio, C. (1961): Plecotteri di Sicilia e d'Aspromonte e classificazione delle Isoperla Europee. Memorie Museo Civico Storia Naturale, Verona, 9: 173-196.

Consiglio, C. (1967): Lista dei Plecotteri della regione Italiana. Fragmenta entomologica. (Roma), 1: $1-66$.

Fochetti R. \& CAMPAdelli, G. (1988): Plecotteri di Romagna: nuove segnalazioni. Bollettino dell' Istituto Entomologico "G. Grandi", Bologna, 43: 63-67.

Fochetti, R. \& CAmpadelli, G. (1991): Nuove acquisizioni sui Plecotteri di Romagna. Bollettino dell'Istituto Entomologico "G. Grandi", Bologna, 46: 63-69.

FOCHETTI, R. \& NiCOLAI, P. (1987): I plecotteri dell'alta valle del fiume Tenna (Monti Sibillini, Italia Centrale) (Plecoptera). Bollettino Associazione Romana Entomologica (Roma), 42: 9-18.

KIS, B. (1974): Plecoptera. Fauna Republicii Socialiste Romania, Bukarest, Insecta, 8, 271 pp.

MuRANYI, D. (2007): New and little-known stoneflies (Plecoptera) from Albania and the neighbouring countries. Zootaxa, 1533: 1-40. doi: $10.11646 /$ zootaxa.1533.1.1

NiCOLAI, P. (1983):. Osservazioni fenologiche sui
Plecotteri di una sorgente abruzzese a temperatura costante (Plecoptera). Bollettino Associazione Romana Entomologica (Roma), 38: 9-19.

NicOlai, P. \& FochetTi, R., (1983): La fauna a Plecotteri di un sistema reocrenico di alta qualitá: il tratto sorgivo del T. Cosa (Monti Ernici, Lazio) (Plecoptera). Rivista di Idrobiologi, 22(2-3): 187202.

NiCOLAI, P. \& FochetTi, R. (1991): Nemoura lucana, a new species from the Italian southern Apennine (Plecoptera, Nemouridae). Aquatic Insects, 13: 245-249. doi: 10.1080/01650429109361451

Nicolai, P., Fochetti, R. \& Dell'Agata, M. (1988): La plecotterofauna del fiume Orfento (Abruzzo, Italia). Atti XV Congresso Nazionale Italiano di Entomologia, L'Aquila, p. 1059-1061

RAVIZZA, C. (1974): Ricerche ecologico-faunistiche sui Plecotteri della Val Staffora (Appennino Lombardo). Bollettino Museo Civico Storia Naturale, Verona, 1: 195-248.

RAVIZZA, C. (1976): Ricerche ecologico-faunistiche sui Plecotteri del torrente Erro (Appennino Ligure) (Plecoptera). Bollettino Museo Civico Storia Naturale, Verona, 3: 331-361.

RAVIZZA, C. \& GERECKE, R. (1991): A review of the distribution of Plecoptera on Sicily. Memorie della Società Entomologica Italiana, 70 (2): 9-31.

Ravizza, C. \& Ravizza Dematteis, E. (1977): La plecotterofauna dell'alta valle del Tanaro (Alpi Liguri) (Plecoptera). Memorie della Società Entomologica Italiana, 55: 182-215.

RAVizzA, C. \& RAVIZZA DEMATTEIS, E. (1983): Sull'ininterrotta presenza di Plecotteri adulti in un ruscello dell'Appennino Ligure occidentale. Analisi della plecotterocenosi e dei periodi di volo (Plecoptera). Redia (Firenze), 66: 615-634.

Ravizza, C. \& Ravizza Dematteis, E. (1986): Les Plécoptères du Grana (Alpes Cottiennes méridionales) (Plecoptera). Bollettino del Museo regionale di Scienze Naturali, Torino, 4(2): 311-339.

RAVizza Dematteis, E. \& RAvizzA, C. (1988): Les Plécoptères de la vallée supérieure du Pô (Alpes Cottiennes). Notes faunistiques et écologiques. Annales de Limnologie (Toulouse), 24(3): 243-260. doi: $\underline{10.1051 / \mathrm{limn} / 1988021}$

RIS, F. (1902): Die schweizerischen Arten der Perlidengattung Nemura. Bulletin de la Société entomologique suisse, 10: 387-405. 
SiveC, I., (1980): Notes on Stoneflies (Plecoptera) from South West Yugoslavia, with Description of a New Nemoura. Aquatic Insects, 2: 91-95 doi: 10.1080/01650428009361012

VINÇON, G. (1996): Les Plécoptères des Alpes françaises. Bulletin de la Société entomologique suisse, 69: 61-75.

VINÇON, G. \& PARDO, I. (2003): Two new Nemoura species from the northwestern Iberian Peninsula and the Pyrenees (Plecoptera, Nemouridae). Nouvelle Revue d'Entomologie (N.S.), 20: 29-38.
VinçON, G., REDING, J.-P.G. \& RAVIZZA, C. (2021): Two new species of Protonemura Kempny, 1898 (Plecoptera: Nemouridae) from the Italian Alps. Zootaxa, 4985(4): 493-512.

doi: $\underline{10.11646 / \text { zootaxa.4985.4.4 }}$

VInÇON, G., RAVIZZA, C. \& REDING, J.-P.G. (2022): Stoneflies (Insecta: Plecoptera) from the Italian region: New species, nomenclatural changes, updated and annotated checklist. Opuscula Zoologica Budapest, In press 